\title{
Prediction of gas pressure in thin coal seams in the Qinglong Coal Mine in Guizhou Province, China
}

\author{
Jian Zhang ${ }^{1}$ Y Yongqiang Zhang ${ }^{2}$ ( ) Jilin Wang ${ }^{3} \cdot$ Xiaobin Wen $^{4}$
}

Received: 15 April 2021 / Accepted: 17 August 2021 / Published online: 2 September 2021

(c) The Author(s) 2021

\begin{abstract}
Thin coal seams in mines usually lack gas data. Thus, preventing and controlling gas outbursts of thin coal seams are difficult. In this study, a coal structure index, which is used to express the damage degree of coal, was estimated by logging curve. In accordance with the contour line of the floor of the coal seam, structural curvature was calculated to express the complexity of the coal seam structure quantitatively. Subsequently, relationships among the burial depth, thickness, coal structure index, structural curvature were analyzed on the basis of the gas pressure of coal seam. The gas pressure values of the coal seams of Nos. 22, 24, and 27 in the study area were predicted by multiple linear regression (MLR) and were then verified and analyzed. The deviation rate of the MLR method was 6.5\%-19.7\%, with an average of $13.0 \%$. The average deviation rate between the predicted value and the measured value was $11.6 \%$, except for the measuring point of No. 2, which had a large deviation. Results show that the prediction accuracy of the aforementioned method is acceptable and has practical value in the prediction of gas pressure in thin coal seams without measured data. The results in the gas pressure prediction provide a basis for evaluating the risk of gas outbursts in thin coal seams.
\end{abstract}

Keywords Gas pressure $\cdot$ Influencing factor $\cdot$ Index $\cdot$ Prediction $\cdot$ Multiple linear regression (MLR)

\section{Introduction}

\section{Understanding of coal seam gas occurrence characteristics}

In mining areas, the occurrence of gas is generally affected by the coalification degree of coal, the permeability of surrounding rocks, the geological structure, and the burial depth and thickness of coal seams (Lu et al. 2019; Li et al. 2020a).

The spatial distribution of gas content is firstly controlled by geological structure. Regional and mine structures form different sealing conditions, which have a considerable

Yongqiang Zhang

smzyq000162@163.com

1 Shaanxi Coalfield Geology Project Management and Consulting Co., Ltd, Xi'an 710054, China

2 Shaanxi Coalfield Geophysical Prospecting and Surveying Co., Ltd, Xi' an 710005, China

3 School of Resources and Geosciences, China University of Mining \& Technology, Xuzhou 221116, China

4 Qinglong Coal Mine of Guizhou Qianxi Energy Development Co., Ltd, Qianxi 551500, China control effect on the distribution of gas content in coal seams (Moore 2012; Gao et al. 2020; Quan et al. 2020). Given a large compressive stress in compressional fault, fault gouge and mylonite with compacted structure are relatively developed, and the permeability of gas is poor (Bustin and Clarkson 1998; Zhang et al. 2016; Tong et al. 2019). Gas migration along the fault or vertical fault plane is relatively difficult, thereby becoming conducive to gas accumulation; meanwhile, the opposite holds for extensional fault. The sealing property is better when the argillaceous content of the roof rock of the coal seam is higher, which is beneficial to gas preservation (Jiang et al. 2010; Zhao et al. 2014b; Li et al. 2018). The greater the burial depth of the coal seam, the larger the in-situ stress and the greater the distance of gas escape, which is also conducive to gas sealing. The greater the thickness of the coal seam, the more conducive it is to gas preservation (Lu et al. 2018b; Kang et al. 2020; Li et al. 2020b). However, some studies have shown that the depth effect is no longer obvious when the depth of coal seam exceeds the critical point of 800-900 $\mathrm{m}$ (Li et al. 2020a).

The geological structure conditions of mining areas considerably influence the present in-situ stress, and the depressions formed by fault structures are high-lying stress areas,

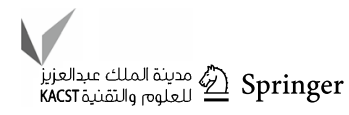


that are conducive to gas preservation (Wang et al. 2018; $\mathrm{Li}$ et al. 2020c; Lu et al. 2021). Given the differences in the associated structures and stress fields above and below the neutral layer, the large fold structures have varying control effects on gas occurrence (Li et al. 2017; Lu et al. 2018a; Meng et al. 2019; Zhang et al. 2020a).

Coal structure is an important factor that affects gas occurrence. Various types of tectonic deformed coal have different physical properties, such as porosity and permeability, which affect gas occurrence (Guo et al. 2014; Song et al. 2017; Liu et al. 2020).

In practice, the gas occurrence law in mining areas must be predicted. Through the pre-analysis of the main influencing factors of gas content or pressure, the analytic algorithm, multiple linear regression (MLR), artificial neural networks, and other methods can achieve satisfactory results (Wei et al. 2009; Dai 2016; Li et al. 2019; Wang et al. 2019). Some scholars use geostatistics method to estimate the gas content of coal seam under GIS environment, which also has a certain effect (Vaziri et al. 2015).

The factors that influence gas occurrence have been studied deeply by previous researchers, and various methods have been used to predict the occurrence law of gas in mining areas. However, for the realization of these methods and the discussion of their reliability, further studies remain necessary to improve the accuracy of gas prediction continuously.

\section{Current development status of thin coal seams}

In China, the thin coal seams were mined early to meet the energy demand of economic construction. The thickness of thin and extremely thin coal seam in China is specified as $0.8-1.3 \mathrm{~m}$ and less than $0.8 \mathrm{~m}$, respectively. Other countries generally set the thickness of thin coal seam as $0.6-0.8 \mathrm{~m}$ and $1.5-1.6 \mathrm{~m}$ at the lower and upper limits, respectively.

In Southern China, including Guizhou Province, the coal bearing strata are mainly in Triassic. The greatest feature of coal seam development is the existence of many coal seams and thin coal seams. At present, literature reports on thin coal seam are scarce, among which Chinese scholars mostly focus on mining simulation experiment (Ma et al. 2008) and fully mechanized mining technology in thin coal seam (Wang et al. 2011; Wang et al. 2012; Zhao et al. 2014a; Liu et al. 2017) and geological or engineering conditions related to thin coal seam mining. The literature related to gas includes the pressure relief mining of protective layer to prevent gas outburst (Li 2014; Cao et al. 2018) and gas drainage technology in thin coal seam (Li 2011; Wang et al. 2017). Other countries in the world that have carried out research on thin coal seams include Poland and Ukraine, mainly Poland. Relevant reports include geological resources and distribution characteristics of thin coal seams (Krowiak
2011), the analysis of reserve proportion of thin coal seams (Dyczko 2007), economic rationality evaluation of thin coal seam mining (Piwniak et al. 2007; Saluga 2008), and discussion on unmanned mining of thin coal seams with advanced consciousness (Litvinsky 2007).

The Guizhou Province is located in the copulae of the circum-Pacific tectonic tract and the Western Tethyan tectonic domain. Its tectonic evolution controls coal-forming environments and gas occurrence. During the Yanshan movement, a series of folds, overthrust fault, and nappe tectonics were formed and resulted the development of tectonic deformed coal. These factors led to serious coal and gas outburst in Guizhou Province (Lu et al. 2020; Zhang et al. 2020b). The Qinglong Coal Mine in the Western Guizhou Province has developed many thin coal seams. The Chinese law stipulates that gas outburst risk assessment must be conducted for thin coal seams with a thickness of more than $0.3 \mathrm{~m}$ (State Administration of Coal Mine Safety 2019). However, obtaining the measured gas data of thin coal seam is difficult in general. So is Qinglong Coal Mine. Under this background, the gas pressure prediction of thin coal seams was conducted by using relevant methods in this study, thereby providing a basis for evaluating the risk of gas outburst in thin coal seams.

Perhaps other countries outside China do not have the urgency of mining thin coal seams at present, but coal resources are non-renewable, and the possibility to continue mining thin coal seams in future is great because of energy demand. Therefore, the research experience and results in the gas prediction of "thin coal seams" are of great significance to the development and utilization of thin coal seams in future.

\section{Geological conditions of coal seam gas}

The Qinglong Coal Mine is approximately located $110 \mathrm{~km}$ Northwest of Guiyang City, Guizhou Province. The length of the mine field from NE to SW is approximately $7.89-9.93 \mathrm{~km}$, the width from NW to SE is approximately $2.31-3.20 \mathrm{~km}$, the area is $20.65 \mathrm{~km}^{2}$, and the mining elevation is between +1300 and $+700 \mathrm{~m}$ (Fig. 1).

The strata exposed in the study area from old to new are the Maokou Formation $\left(\mathrm{P}_{2} m\right)$ of the Middle Permian, the Emeishan basalt formation $\left(\mathrm{P}_{3} \beta\right)$, the Longtan $\left(\mathrm{P}_{3} l\right)$ and Changxing Formations $\left(\mathrm{P}_{3} c\right)$ of the Upper Permian, and the Yelang $\left(\mathrm{T}_{1} y\right)$ and Maocaopu Formations $\left(\mathrm{T}_{1} m\right)$ of the Lower Triassic, and Quaternary $(\mathrm{Q})$. The coal bearing strata in the study area include the Longtan Formation $\left(\mathrm{P}_{3} l\right)$ of the Upper Permian, which can be divided into $\mathrm{P}_{3} l^{1}$ and $\mathrm{P}_{3} l^{2}$ in accordance with lithologic association. The thickness of $\mathrm{P}_{3} l$ is $158.50-188.30 \mathrm{~m}$, and the average is $172.05 \mathrm{~m}$. 
Fig. 1 Structural outline and geographical location of Qinglong Coal Mine

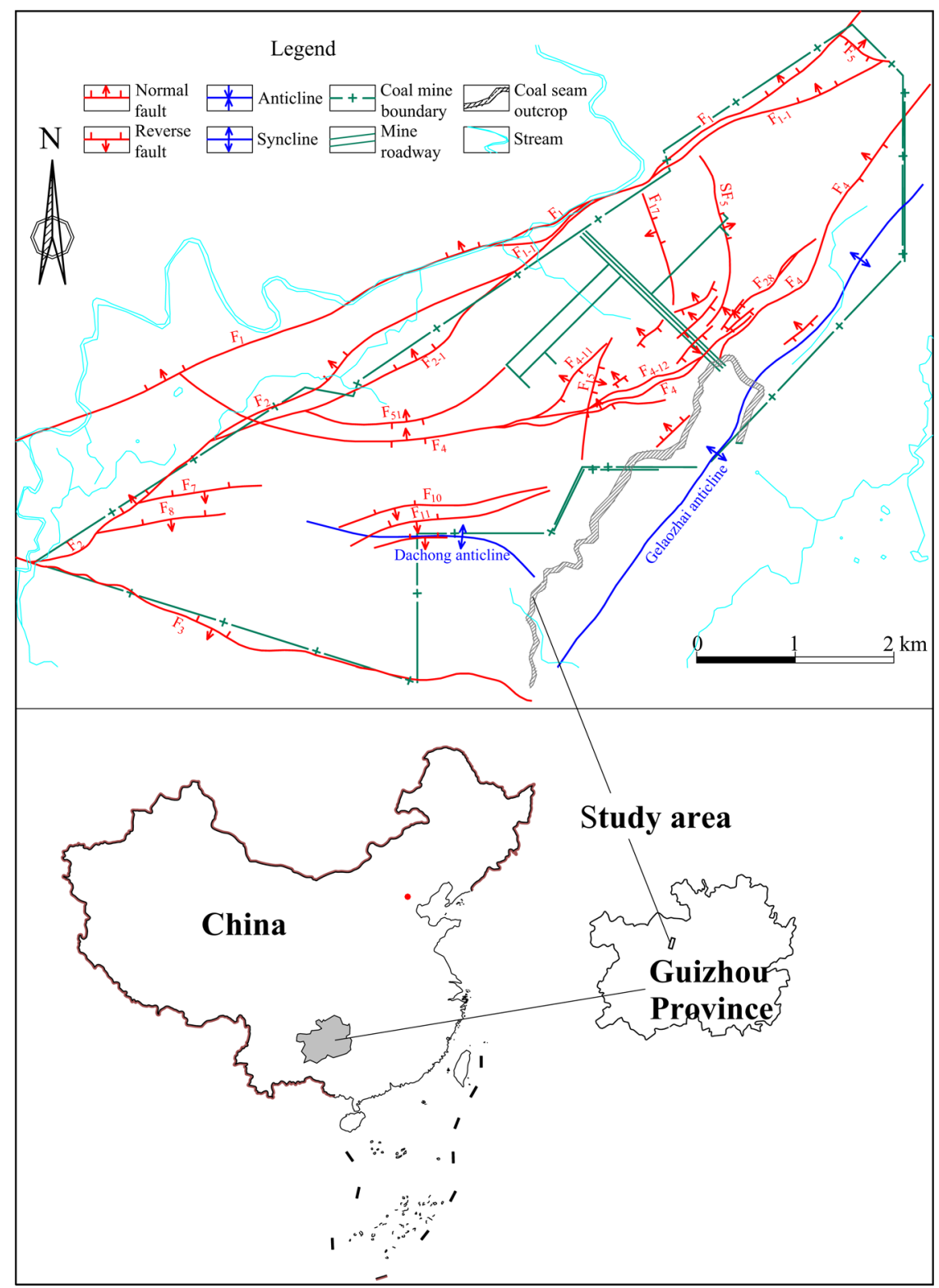

The structural features of the study area mainly include a series of wide and gentle folds with NE or NNE trends. The study area is located in the Northwest wing of the Gelaozhai anticline, and its structural characteristics are consistent with the regional tectonic framework. The mine field is dominated by NE trending structures with normal and reverse faults, large-scale and long extensions, and large dip angles. The secondary faults are mainly reverse faults with smallscale and short extensions (Fig. 1). Mining and excavation data show that small faults and folds are well developed in the mine field. Most of them are faults with a throw of $0.5-10 \mathrm{~m}$, and the dip angle of the small fold strata varies from 3 to $90^{\circ}$.

The entire coal bearing strata has 15-26 coal seams, including 9 minable and partially minable coal seams
(Nos. 2, 3, 16, 17, 18, 22, 24, 27, and 30). The coal seams of Nos. 16 and 18 are the main minable coal seams. The average thickness of all coal seams is $16.26 \mathrm{~m}$, and the coal bearing coefficient is $9.5 \%$. Although the distribution of these thin coal seams is unstable, partially minable or not, the gas content is high and has the risk of gas outburst. For example, the average thickness of the coal seam of No. 22 is $1.23 \mathrm{~m}$, and gas outburst occurs many times when the coal seam has been exposed. 


\section{Main influencing factors and indexes of gas pressure}

Gas pressure is an important index for the risk assessment of gas outbursts in coal seam. However, measured data of gas pressure in thin coal seam at the initial stage of mining are lacking due to the unstable distribution and partial minability. Therefore, the gas pressure of thin coal seams must be predicted to ensure production safety.

The coal seam of Nos. 16 and 18 in the study area have substantial gas data. Data on burial depth, coal thickness, coal structure index, and structural curvature of coal seam were analyzed by single-factor analysis, and gas pressure have a certain correlation with the aforementioned factors (Fig. 2). Among these four indexes, data on burial depth and thickness of coal seam could be directly obtained,
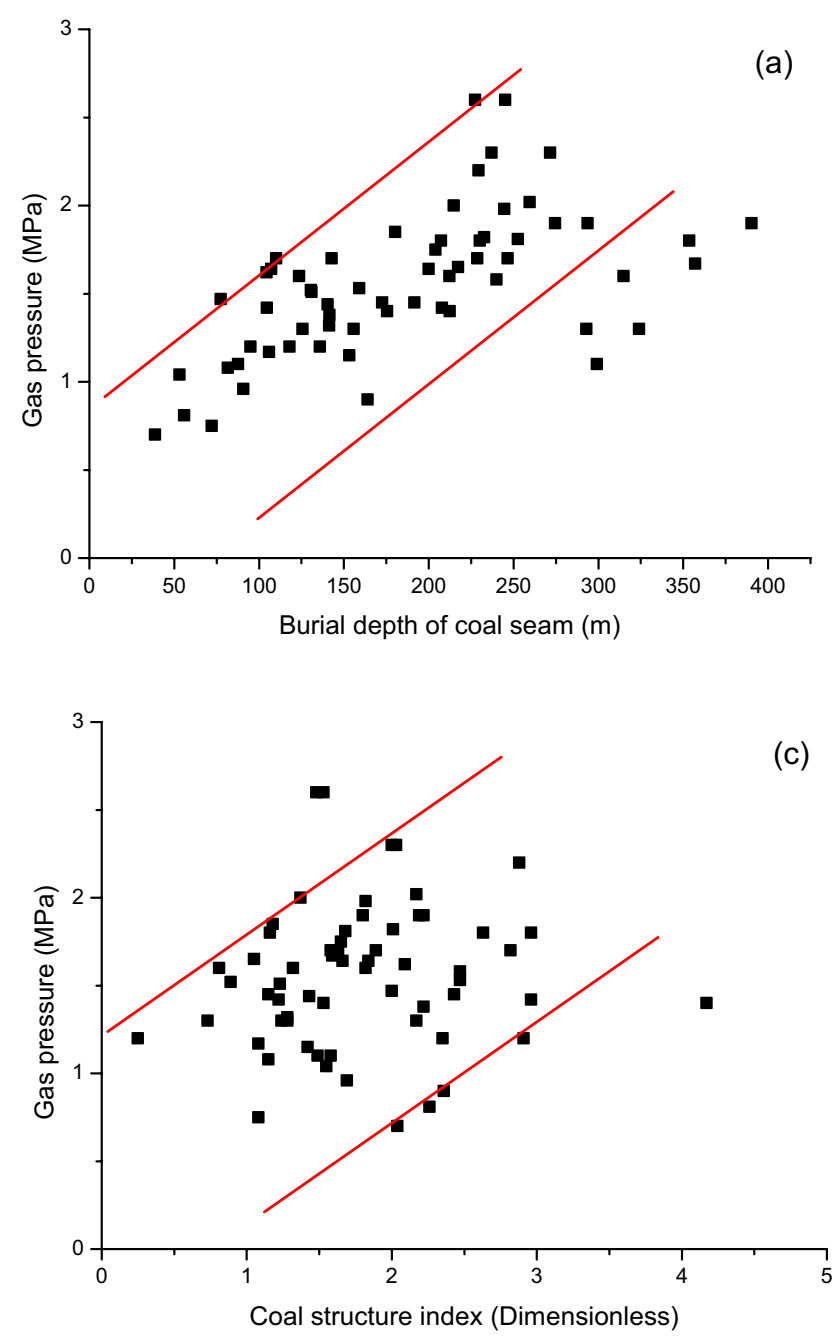

Fig. 2 Correlation between gas pressure and influencing factors whereas those on coal structure index and tectonic curvature must be indirectly obtained through calculation.

\section{Calculation of coal structure index}

Among the commonly used logging curves in coal field geological exploration, the apparent resistivity curve (DLW) and artificial gamma curve (HGG) are the obvious indexes that reflect the difference in the degree of coal damage. Given that pore and fracture are well developed in damaged coal, the water content of coal increases under the immersion of drilling fluid, which leads to the decrease in the amplitude of DLW and the increase in the amplitude of HGG in coal seams with a high degree of damage. The changes in these two curves are the main bases for judging the degree of damage in coal (Fu et al. 2003). The variation of well diameter can also be used as a reference. The coal with a higher
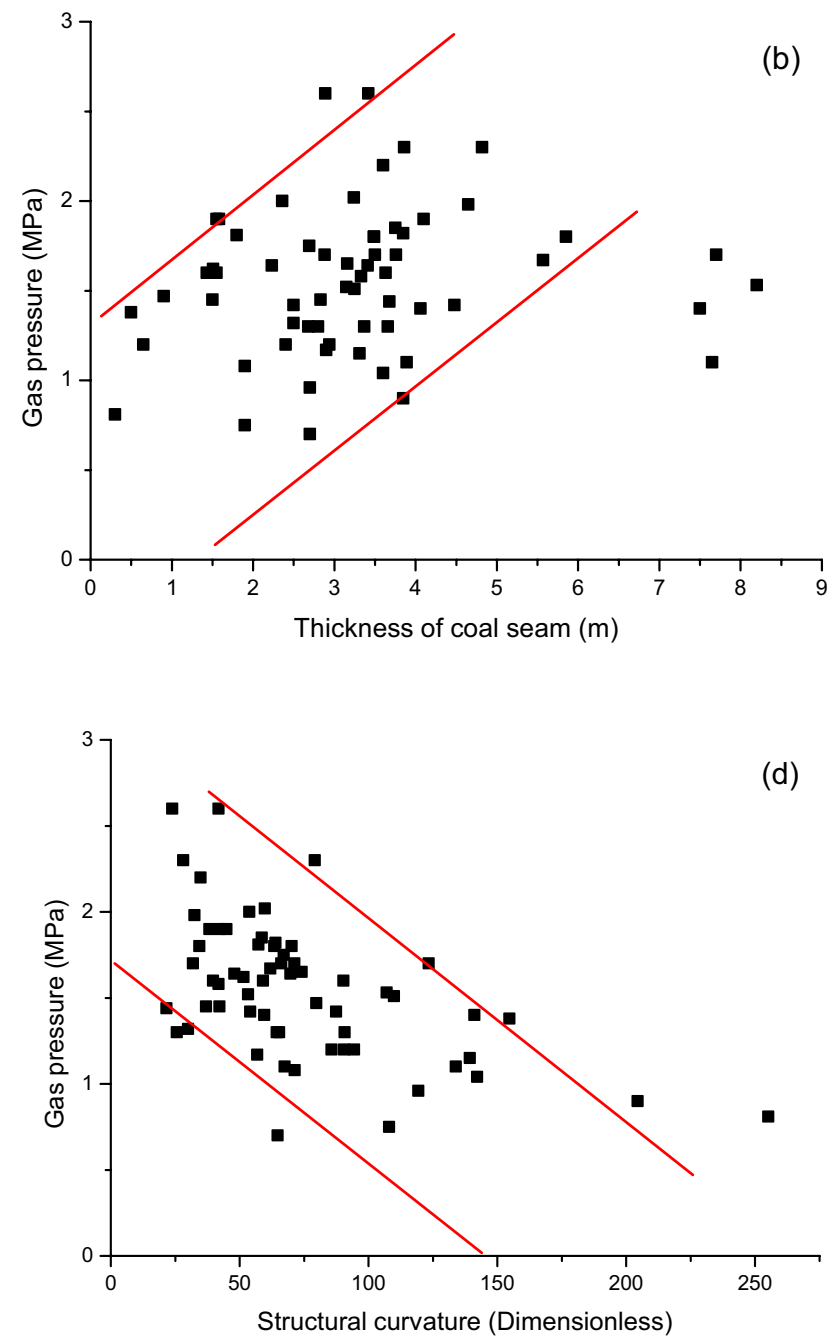
damage degree usually causes the enlargement of the well diameter (Fig. 3).

At this point, the degree of coal damage can be categorized into three levels: the value of $0-1$ represent no to small damage, the value of 1-2 represent moderate damage, and the value of $2-\geq 3$ represent relatively large damage to large damage.

In accordance with the above principles, the values of DLW, HGG, and borehole diameter change were calculated to determine the degree of coal failure comprehensively.

Apparent resistivity (Unit: $\Omega \cdot \mathrm{M}$ ):

$$
\left(1-\frac{\left|X_{i}-X_{\min }\right|}{\left|X_{\max }-X_{\min }\right|}\right) \times 3
$$

Artificial gamma (Unit: CPS) and change in borehole diameter (Unit: $\mathrm{mm}$ ):

$$
\frac{\left|X_{i}-X_{\min }\right|}{\left|X_{\max }-X_{\min }\right|} \times 3
$$

where $X_{i}$ is the reading value of the logging curve of the borehole, $X_{\min }$ is the minimum reading value of the logging curve, and $X_{\max }$ is the maximum reading value of the logging curve reading.

\section{Calculation of construction curvature}

Structural curvature is a dimensionless value calculated in accordance with the shape, density, and bending degree of the coal seam floor's contour line, which can reflect the deformation degree of the coal seam floor well. The curvature of the contour line of the coal seam floor can reflect the local change in the morphology of the coal seam floor; and this curvature is equivalent to the reflection of the structural form of the coal seam. The calculation formula is expressed as follows (Shen et al. 2010):
$K=\frac{\left|z^{\prime \prime}\right|}{\left(1+z^{\prime}\right)^{3 / 2}}$

where $K$ is the curvature value of a point in the coal seam floor; $z$ is the coal seam floor elevation, $z=f(x, y), z^{\prime}=\frac{\partial f}{\partial x}$, and $z^{\prime \prime}=\frac{\partial f^{\prime}}{\partial x}$.

The contour lines of the coal seam floor were divided into many square cells with $500 \mathrm{~m} \times 500 \mathrm{~m}$. The curvature of the floor contour lines in the North, East, South, and West directions were calculated at the center point of the cells, and the maximum value was taken as the structural curvature of the calculation point. Through this method, the structural curvature of the floor of the coal seam with No. 22 in the study area was calculated (Fig. 4).

\section{Prediction and comparison of gas pressure}

\section{Prediction by MLR}

With $Y$ taken as variable, and burial depth, coal thickness, coal structure index, and structural curvature taken as explanatory variables $X, X=\left\{X_{1}, X_{2}, X_{3}, X_{4} . X_{i} \in(0,+\infty)\right\}$, on the basis of 62 groups of data (hereinafter referred to as "early measured data") measured in the early stage of the coal seams of Nos. 16 and 18, MLR analysis was conducted in accordance with the following formula:

$Y=b_{0}+b_{1} X_{1 i}+b_{2} X_{2 i}+b_{3} X_{3 i+} b_{4} X_{4 i}, i=1,2,3, \ldots, n$,

where $Y$ is the gas pressure, $\mathrm{MPa} ; X$ is the explanatory variable; $X_{1}$ is the burial depth, $\mathrm{m} ; X_{2}$ is the coal thickness, $\mathrm{m} ; X_{3}$ is the coal structure index (dimensionless); $X_{4}$ is the structural curvature (dimensionless); $b$ is the regression coefficient, $b=\left(b_{0}, b_{1}, b_{2}, b_{3}, b_{4}\right)$; and $\mathrm{n}$ is the sample number of MLR, $n=62$.

MLR analysis was conducted through programming calculation. Regression results, such as regression coefficient

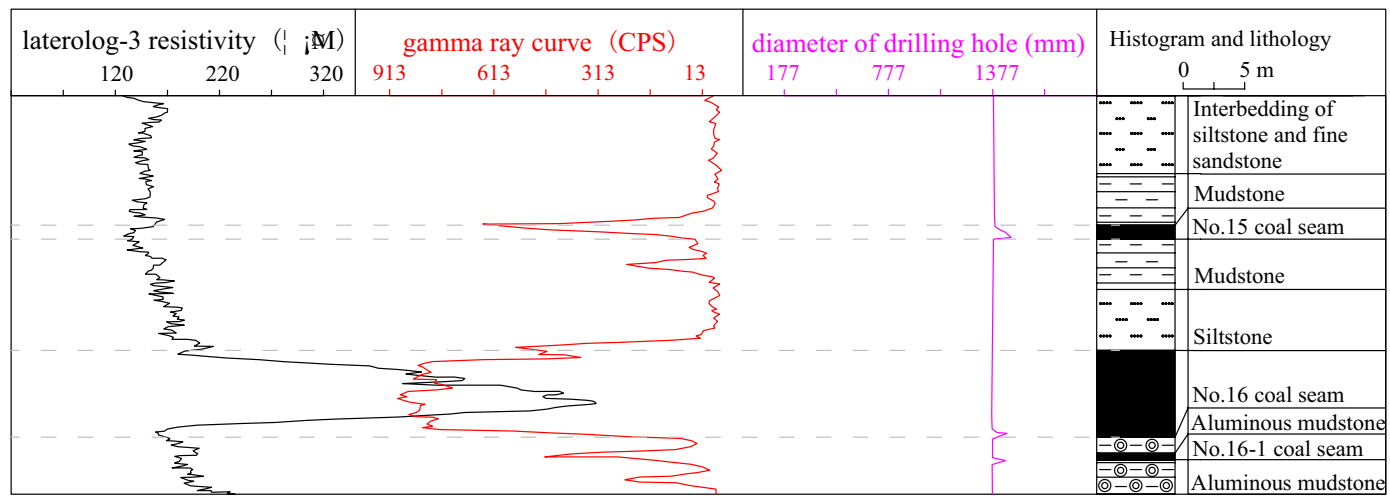

Fig. 3 Logging curve characteristics related to coal structure index 
Fig. 4 Structural curvature of the coal seam No. 22

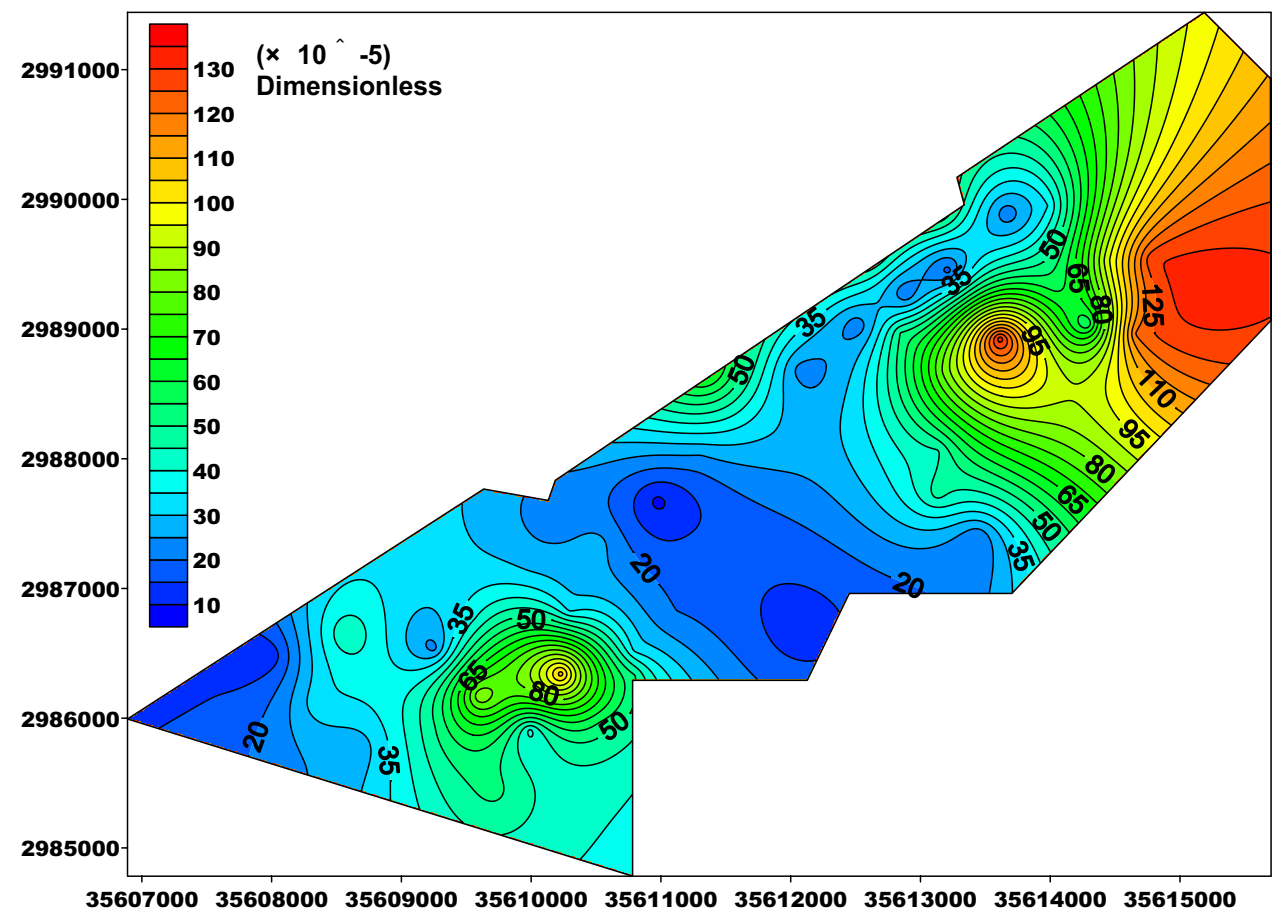

Table 1 Results in the MLR of gas pressure

\begin{tabular}{lcc}
\hline Regression coefficient & $\begin{array}{l}\text { Estimation of } \\
\text { regression coef- } \\
\text { ficient }\end{array}$ & $\begin{array}{l}\text { Confidence interval } \\
\text { of regression coef- } \\
\text { ficient }\end{array}$ \\
\hline$b_{0}$ & 1.3185 & $(0.9598,1.6773)$ \\
$b_{1}$ & 0.0020 & $(0.0009,0.0031)$ \\
$b_{2}$ & 0.0055 & $(-0.0450,0.0560)$ \\
$b_{3}$ & 0.0633 & $(-0.0574,0.1840)$ \\
$b_{4}$ & -0.0036 & $(-0.0057,-0.0016)$ \\
$R=0.6779$, confidence level $\alpha=0.05, F=12.1176$
\end{tabular}

estimation value, regression coefficient confidence interval, and similarity coefficient, were obtained (Table 1).

In this MLR, confidence level $\alpha=0.05$, degree of free$\operatorname{dom} k_{1}=4, k_{2}=n-k_{1}-1=62-k_{1}-1=57$.

According to the table, $F_{0.05}\left(k_{1}, k_{2}\right)=F_{0.05}(4,57)=2.53$; therefore, $F=12.12>F_{0.05}(4,57)=2.53$, and the regression model was established. Therefore, Formula (5) could be used to describe the fitting relationship between gas pressure $(Y)$ and burial depth $\left(X_{1}\right)$, coal thickness $\left(X_{2}\right)$, coal structure index $\left(X_{3}\right)$, and structural curvature $\left(X_{4}\right)$ as follows.

$Y=1.3185+0.0020 X_{1}+0.0055 X_{2}+0.0633 X_{3}-0.0036 X_{4}$,

where $Y$ is the gas pressure, MPa.

In accordance with the MLR relationship between gas pressure and the various indexes (Formula (5)), the predicted gas pressure values of the coal seams of Nos. 22, 24, and 27 could be obtained (Table 2).

The predicted gas pressure values of the coal seams of Nos. 22, 24, and 27 were accordingly plotted. The plots show that the gas pressure of each coal seam from shallow to deep is approximately $1.2-3.0 \mathrm{MPa}$, thereby gradually increasing from NE to SW overall (Fig. 5).

\section{Systematic deviation revision of different batches of data}

Six months after the completion of this study, three gas test holes were constructed in a mining area, and some test data were obtained (Table 3). These newly measured data are called "current measured data". The "early measured data" mentioned above are only the data of the thicker coal seams of Nos. 16 and 18; whereas other thin coal seams lack data. The purpose of this test is to obtain the gas pressure of the thin coal seam. Therefore, the current measured data include not only the gas pressure data of the thin coal seam but also the gas pressure data of the coal seams of Nos. 16 and 18 . In accordance with these test data, the prediction results can be verified and compared.

In accordance with the "early measured data" of gas pressure in the coal seams Nos. 16 and 18, a contour map of gas pressure was drawn, and test holes $\mathrm{Z} 1-\mathrm{Z} 3$ are superimposed in Fig. 6. The early measured gas pressure values of holes $\mathrm{Z1}-\mathrm{Z} 3$ could be obtained from the figure. However, a certain deviation exists between the values 
Table 2 Predicted results in MLR of gas pressure (partial data)

\begin{tabular}{|c|c|c|c|c|c|c|}
\hline Coal seam No & Hole No & $\begin{array}{l}\text { Floor burial } \\
\text { depth }(\mathrm{m})\end{array}$ & $\begin{array}{l}\text { Coal thick- } \\
\text { ness }(m)\end{array}$ & $\begin{array}{l}\text { Coal structure index } \\
\text { (dimensionless) }\end{array}$ & $\begin{array}{l}\text { Structural curvature } \\
\left(\times 10^{-5}\right) \text { (dimensionless) }\end{array}$ & $\begin{array}{l}\text { Predicted value of } \\
\text { gas pressure (MPa) }\end{array}$ \\
\hline \multirow[t]{10}{*}{22} & $\mathrm{Z1}-2$ & 274.77 & 2.55 & 3.30 & 34.88 & 1.97 \\
\hline & $\mathrm{Z} 2-4$ & 294.63 & 1.26 & 3.15 & 21.80 & 2.04 \\
\hline & Z4-2 & 265.11 & 1.27 & 2.20 & 20.91 & 1.92 \\
\hline & Z4-3 & 308.94 & 0.55 & 2.75 & 56.52 & 1.91 \\
\hline & $\mathrm{Z} 5-2$ & 280.45 & 1.26 & 1.93 & 21.76 & 1.93 \\
\hline & Z5-3 & 312.94 & 1.78 & 3.00 & 46.49 & 1.98 \\
\hline & Z6-3 & 273.99 & 1.28 & 1.99 & 23.01 & 1.92 \\
\hline & Z7-4 & 264.49 & 1.08 & 2.31 & 37.21 & 1.87 \\
\hline & $\mathrm{Z7}-5$ & 332.97 & 0.57 & 1.64 & 70.40 & 1.84 \\
\hline & Z8-3 & 268.26 & 1.27 & 2.56 & 23.76 & 1.94 \\
\hline \multirow[t]{10}{*}{24} & $\mathrm{Z} 1-2$ & 297.31 & 1.45 & 2.23 & 47.91 & 1.89 \\
\hline & $\mathrm{Z} 2-4$ & 316.23 & 0.88 & 2.75 & 63.27 & 1.90 \\
\hline & Z4-2 & 279.57 & 1.13 & 2.06 & 29.77 & 1.91 \\
\hline & Z4-3 & 327.16 & 0.92 & 3.10 & 24.36 & 2.09 \\
\hline & $\mathrm{Z5}-2$ & 294.8 & 0.6 & 2.00 & 33.49 & 1.92 \\
\hline & Z5-3 & 327.67 & 0.99 & 2.18 & 4.91 & 2.10 \\
\hline & Z6-3 & 288.08 & 1.28 & 2.07 & 14.34 & 1.98 \\
\hline & Z7-4 & 279.86 & 0.79 & 1.99 & 24.1 & 1.92 \\
\hline & $\mathrm{Z7}-5$ & 347.03 & 0.86 & 0.54 & 33.85 & 1.93 \\
\hline & Z8-3 & 279.95 & 0.88 & 2.32 & 62.9 & 1.80 \\
\hline \multirow[t]{10}{*}{27} & Z1-2 & 315.59 & 0.58 & 1.18 & 21.91 & 1.95 \\
\hline & Z2-4 & 335.75 & 0.65 & 2.07 & 15.96 & 2.07 \\
\hline & Z4-2 & 300.92 & 1.24 & 1.51 & 22.81 & 1.94 \\
\hline & Z4-3 & 352.14 & 1.14 & 2.36 & 51.99 & 1.99 \\
\hline & Z5-2 & 315.8 & 1.03 & 1.58 & 19.08 & 1.99 \\
\hline & Z5-3 & 356.41 & 1.34 & 1.81 & 49.41 & 1.98 \\
\hline & Z6-3 & 314.03 & 2.17 & 2.05 & 18.68 & 2.02 \\
\hline & Z7-4 & 306.06 & 1.95 & 2.04 & 25.90 & 1.98 \\
\hline & Z7-5 & 374.81 & 2.02 & 1.00 & 52.11 & 1.96 \\
\hline & Z8-3 & 304.75 & 1.7 & 2.32 & 174.77 & 1.45 \\
\hline
\end{tabular}

obtained in the figure and the corresponding values of the current measured data (Table 4).

As shown in Table 4, the values between the previous and later measurements are inconsistent, and the deviation rate is discrete. Determining which of the data are more reliable is impossible because they are all measured values at different times; thus, the maximum and minimum values of the deviation rate are eliminated, and then the average value of the middle values of the deviation rate is regarded as the system error. In this manner, the system error of the current measured value is considered $0.22 \mathrm{MPa}$. Therefore, the current measured value needs to be corrected. In other words, $0.22 \mathrm{MPa}$ should be subtracted from the current measured value to match the early measured value.

\section{Discussion on prediction results}

In accordance with the above adjustment principles, the predicted gas pressure values of the coal seams of Nos. 22, 24, and 27 were verified and compared (Table 5). As shown in Table 5, the deviation rate of the prediction results of MLR ranges from 6.5 to $19.7 \%$, with an average of $13.0 \%$, with the correction values of the measured values taken as the verification standard.

In addition, among the six measuring points, the prediction effect of measuring point No. 2 (coal seam No.22 of borehole $\mathrm{Z2}$ ) is poor, and the reasons need to be discussed further. The predicted values of other measuring points are close to the measured values. The average deviation rate between the predicted and measured values is 
Fig. 5 Prediction results of gas pressure in the coal seams of Nos.22, 24 and 27

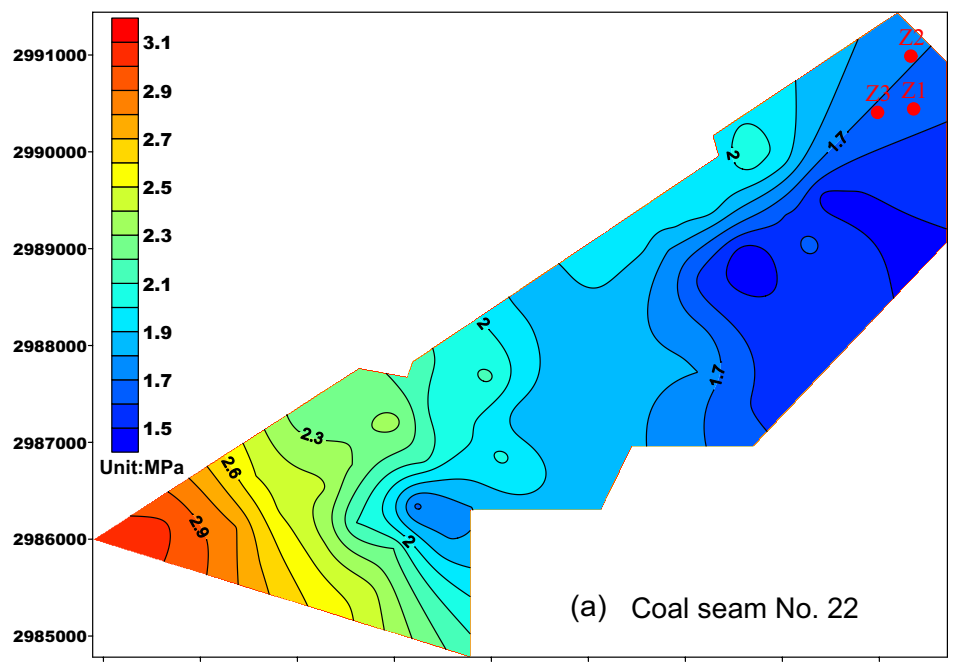

356070003560800035609000356100003561100035612000356130003561400035615000

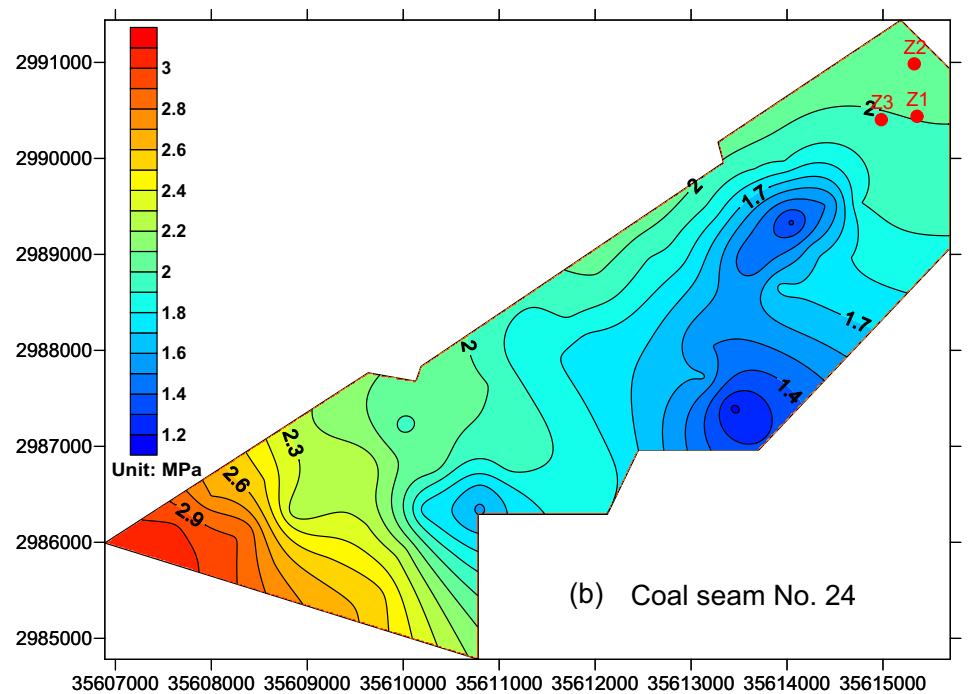

356070003560800035609000356100003561100035612000356130003561400035615000

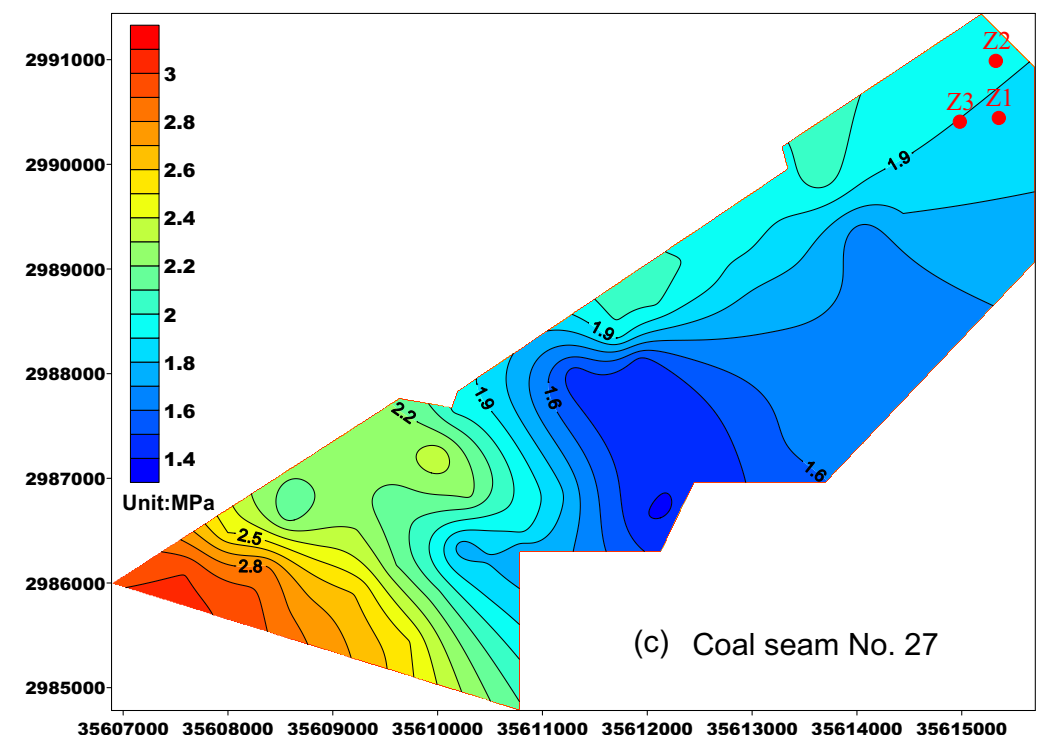

356070003560800035609000356100003561100035612000356130003561400035615000 
Table 3 Results in borehole gas pressure test

\begin{tabular}{lllll}
\hline Hole No & Coal seam No & $\begin{array}{l}\text { Depth of roof and floor of } \\
\text { coal seam (m) }\end{array}$ & $\begin{array}{l}\text { Vertical thickness of } \\
\text { coal seam (m) }\end{array}$ & $\begin{array}{l}\text { Borehole gas } \\
\text { pressure (MPa) }\end{array}$ \\
\hline $\mathrm{Z} 1$ & 16 & $208.14-211.15$ & 3.01 & 1.78 \\
& 18 & $251.43-255.80$ & 4.37 & 1.98 \\
& 22 & $301.62-302.52$ & 0.90 & 2.13 \\
& 24 & $316.00-317.49$ & 1.49 & 2.37 \\
& 27 & $333.94-334.97$ & 1.03 & 2.42 \\
$\mathrm{Z} 2$ & 16 & $272.60-273.80$ & 1.20 & 2.09 \\
& 18 & $307.81-310.75$ & 2.94 & 2.68 \\
& 22 & $345.60-346.83$ & 1.23 & 2.35 \\
& 24 & $362.58-363.60$ & 1.02 & 2.49 \\
& 27 & $301.65-302.45$ & 0.80 & 2.45 \\
\hline
\end{tabular}

$11.6 \%$, except for measuring point No. 2; this result is acceptable in actual production.

The research in gas prediction has two trends, one is to select different prediction methods, and the other is to choose different influencing factor indexes in the research. The main method different from this paper is artificial neural network (ANN) (Wei et al. 2009; Li et al. 2019). Although this method have its advantages, it first needs to learn and train the model and ensure the convergence of the training process, which requires enough data for learning, and even needs to optimize the parameters of the model. The use of ANN has also been attempted in the research of this case, but its effect is not as good as that of MLRs, so it is not adopted.

As for the influencing factor indicators, the buried depth of coal seam is generally recognized as one of the main influencing factors, and other influencing factor indicators vary from researchers to researchers, such as the roof and floor lithology of the seam, coal physical indicators, coal quality indicators, and geophysical detection signal data. Of course, these data are more or less related to coal seam gas content. However, these indicators are not necessarily easy to obtain, especially the physical or chemical indicators of coal, which need to be tested. In addition, geophysical signal data are actually the indirect response of the object of relevant influencing factors. The indicators used in this case covered the main influencing factors of coal seam gas, which can be easily obtained directly or through calculation. Hence, it is conducive to the popularization and application of this method.

In summary, the MLR method has practical application value in the prediction of gas pressure in thin coal seams of coal mines. Given that the appropriate and quantitative influencing factors are selected, a satisfactory prediction effect can be achieved.

\section{Conclusions}

(1) Gas occurrence in coal seam is influenced by many factors, such as burial depth, coal thickness, coal structure, and geological structure, and the quantitative indexes of which can be used to predict gas pressure.

(2) The structural condition of coal can be expressed by the structural index of coal, which can reflect the degree of coal damage. The structural index of coal can be evaluated synthetically by using DLW, HGG, and drilling diameter change.

(3) Geological structure can be expressed by the development degree of faults and folds. For the structural deformation of multiple coal seams, the structural curvature can be calculated in accordance with the contour line of the coal seam floor, which can describe the structural development degree of different coal seams objectively and quantitatively.

(4) In the study of gas pressure prediction of several thin coal seams in the Qinglong Coal Mine in Guizhou Province, the deviation rate of the prediction results of MLR ranges from 6.5 to $19.7 \%$, with an average of $13.0 \%$. Except for that of measuring point No. 2, the average deviation rate between the predicted and measured values of the five other measuring points is $11.6 \%$, which is acceptable in actual production. This result shows that the MLR method has practical value in gas pressure prediction in thin coal seams without measured data. 
Fig. 6 Contour map of gas pressure in the coal seams of Nos.16 and 18
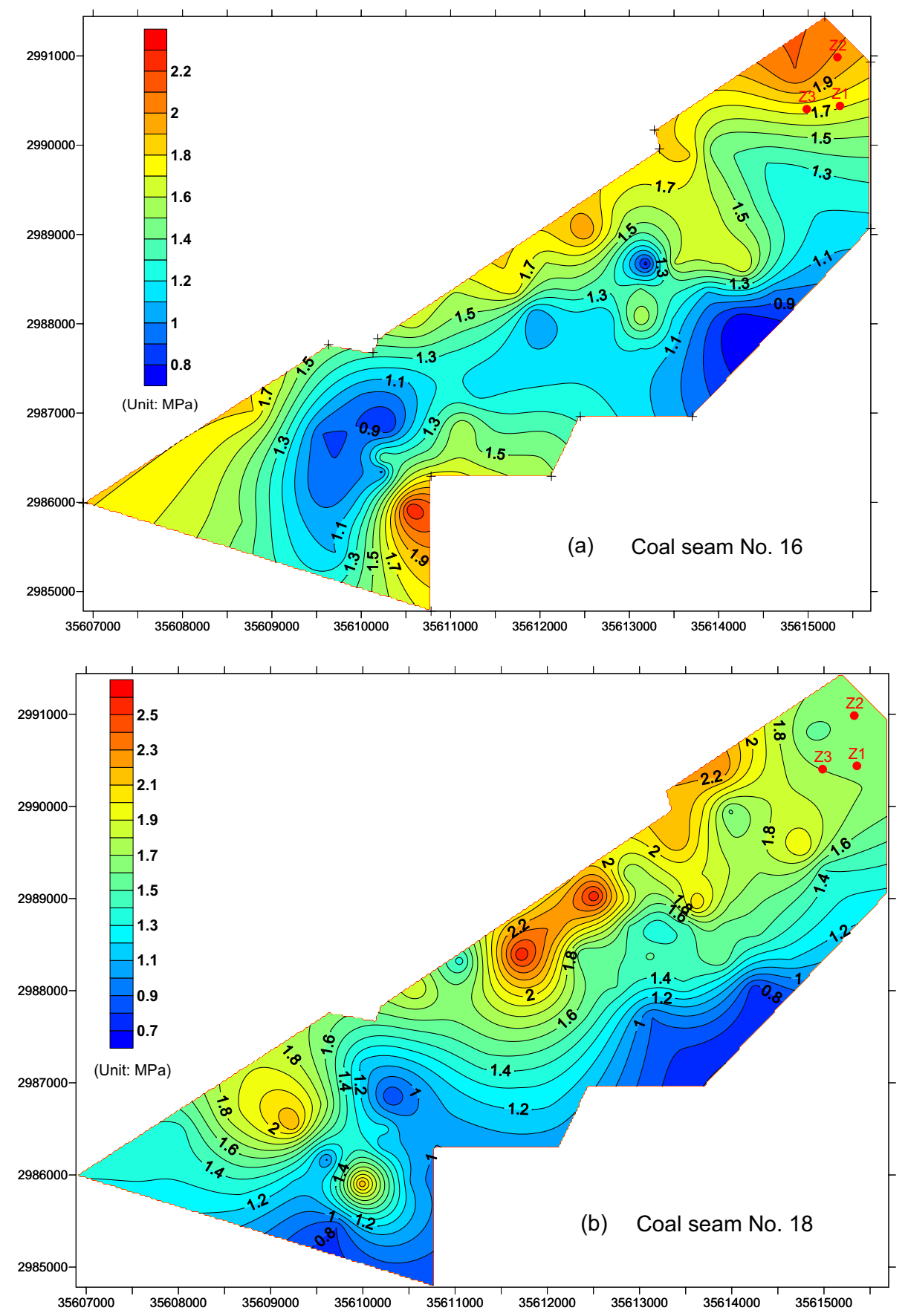

Table 4 Comparison of the measured values of gas pressure in the coal seams of Nos.16 and 18

\begin{tabular}{lllllll}
\hline Coal seam No & Hole No & $\begin{array}{l}\text { Early measured } \\
\text { data (MPa) }\end{array}$ & $\begin{array}{l}\text { Current measured } \\
\text { data (MPa) }\end{array}$ & $\begin{array}{l}\text { Deviation } \\
(\mathrm{MPa})\end{array}$ & $\begin{array}{l}\text { Deviation rate } \\
\text { Mean deviation of } \\
\text { current measured data } \\
(\mathrm{MPa})\end{array}$ \\
\hline 16 & $\mathrm{Z} 1$ & 1.70 & 1.78 & 0.08 & $4.5 \%$ & Eliminate \\
18 & $\mathrm{Z} 2$ & 1.95 & 2.09 & 0.14 & $6.7 \%$ & 0.22 \\
& $\mathrm{Z} 1$ & 1.68 & 1.98 & 0.30 & $15.2 \%$ & Eliminate \\
\hline
\end{tabular}


Table 5 Verification and comparison of the predicted gas pressure values of coal seam Nos.22, 24, and 27

\begin{tabular}{|c|c|c|c|c|c|c|c|}
\hline \multirow[t]{2}{*}{ No } & \multirow[t]{2}{*}{ Coal seam No } & \multirow[t]{2}{*}{ Hole No } & \multicolumn{3}{|c|}{ Corrected measured data (MPa) } & \multicolumn{2}{|c|}{ Predicted value of MLR (MPa) } \\
\hline & & & Original value & System error & Corrected value & Predicted value & Deviation rate \\
\hline 1 & 22 & $\mathrm{Z1}$ & 2.13 & 0.22 & 1.91 & 1.65 & $13.6 \%$ \\
\hline 2 & & $\mathrm{Z} 2$ & 2.35 & & 2.13 & 1.71 & $19.7 \%$ \\
\hline 3 & 24 & $\mathrm{Z} 1$ & 2.37 & & 2.15 & 2.01 & $6.5 \%$ \\
\hline 4 & & $\mathrm{Z} 2$ & 2.49 & & 2.27 & 2.07 & $8.8 \%$ \\
\hline 5 & 27 & $\mathrm{Z} 1$ & 2.42 & & 2.20 & 1.88 & $14.5 \%$ \\
\hline 6 & & Z3 & 2.45 & & 2.23 & 1.90 & $14.8 \%$ \\
\hline
\end{tabular}

Funding This research was financially supported by the "Climate Change: Carbon Budget and Related Issues" Strategic Priority Research Program of the Chinese Academy of Sciences (Grant No. XDA05030100).

\section{Declarations}

Conflict of interest No conflict of interest exits in the submission of this manuscript, and manuscript is approved by all authors for publication.

Open Access This article is licensed under a Creative Commons Attribution 4.0 International License, which permits use, sharing, adaptation, distribution and reproduction in any medium or format, as long as you give appropriate credit to the original author(s) and the source, provide a link to the Creative Commons licence, and indicate if changes were made. The images or other third party material in this article are included in the article's Creative Commons licence, unless indicated otherwise in a credit line to the material. If material is not included in the article's Creative Commons licence and your intended use is not permitted by statutory regulation or exceeds the permitted use, you will need to obtain permission directly from the copyright holder. To view a copy of this licence, visit http://creativecommons.org/licenses/by/4.0/.

\section{References}

Bustin RM, Clarkson CR (1998) Geological controls on coalbed methane reservoir capacity and gas content. Int J Coal Geol 38(1-2):326. https://doi.org/10.1016/S0166-5162(98)00030-5

Cao ZY, He XQ, Wang EY, Kong B (2018) Protection scope and gas extraction of the low-protective layer in a thin coal seam: lessons from the DaHe coalfield. China Geosci J 22(3):487-499. https:// doi.org/10.1007/s12303-017-0061-1

Dai LC (2016) Research status and prospects of coal seam gas content prediction based on mathematical model. Proc 2016 6th Int Conference Appl Sci Eng Technol 158-162. https://doi.org/10.2991/ icaset-16.2016.32

Detailed rules for prevention and control of coal and gas outburst (2019) State administration of coal mine safety of the People's Republic of China

Dyczko A (2007) Thin coal seams, their role in the reserve base of Poland technical, technological and economic aspects of thinseams coal mining. Inter Mining Forum 2007:81-87. https://doi. org/10.1201/noe0415436700.ch10

Fu XH, Jiang B, Qin Y (2003) Classification of coalbody structure and prediction of coal reservoir permeability with log curves. Well Logging Technol 27(2):140-143
Gao Z, Ma DM, Chen Y, Zheng C, Teng JX (2020) Study for the effect of temperature on methane desorption based on thermodynamics and kinetics. ACS Omega. https://doi.org/10.1021/acsomega. 0c05236

Guo DY, Li CJ, Zhang YY (2014) Contrast study on porosity and permeability of tectonically deformed coal and indigenous coal in Pingdingshan mining area, China. Earth Sci J China Univ Geosci 39:1600-1606

Jiang B, Qu ZH, Wang GG, Li M (2010) Effects of structural deformation on formation of coalbed methane reservoirs in Huaibei coalfield. China. Int J Coal Geol 82(3-4):175-183. https://doi. org/10.1016/j.coal.2009.12.011

Kang GX, Kang TH, Guo JQ, Kang JT, Zhang RX, Zhang XY, Zhao GF, Zhang B, Li LG, Zhang LK (2020) Effect of electric potential gradient on methane adsorption and desorption behaviors in lean coal by electrochemical modification: implications for coalbed methane development of Dongqu mining. China. ACS Omega 5(37):24073-24080. https://doi.org/10.1021/acsomega.0c03496

Krowiak A (2011) Features of the resources of the hard coal covering in thin coal-seams in Poland. In: Bondarenko Volodymyr, Kovalevs'ka Iryna (eds) Genadiy Pivnyak. CRC Press, Tech Geoinformational Syst Min, pp 141-148

Li WG (2011) Experimental study on gas extraction methods in Sichuan basin Xujiahe formaton extremely thin coal seam. Procedia Earth Planetary Sci 2:127-132. https://doi.org/10.1016/j. proeps.2011.09.021

Li DQ (2014) Mining thin sub-layer as self-protective coal seam to reduce the danger of coal and gas outburst. Nat Hazards 71:41-52. https://doi.org/10.1007/s11069-013-0898-1

Li D, Peng SP, Du WF, Guo YL (2019) New method for predicting coal seam gas content. Energy Sour Part A-Recover Utilization Environ Effects 41(10):1272-1284. https://doi.org/10.1080/15567 036.2018 .1545003

Li W, Jiang B, Moore TA, Wang G, Liu JG, Song Y (2017) Characterization of the chemical structure of tectonically deformed coals. Energy Fuels 31(7):6977-6985. https://doi.org/10.1021/acs.energ yfuels.7b00901

Li QS, He X, Wu JH, Ma S (2018) Investigation on coal seam distribution and gas occurrence law in Guizhou China. Energy Explor Exploit 36(5):1310-1334. https://doi.org/10.1177/0144598718 758068

Li PP, Zhang XD, Li J, Zhao JP, Huang JP, Zhang S, Zhou SX (2020a) Analysis of the key factors affecting the productivity of coalbed methane wells: a case study of a high-rank coal reservoir in the central and southern Qinshui basin China. ACS Omega 5(43):28012-28026. https://doi.org/10.1021/acsomega.0c03540

Li XC, Chen XL, Zhang F, Zhang MT, Zhang Q, Jia SY (2020b) Energy calculation and simulation of methane adsorbed by coal with different metamorphic grades. ACS Omega 5(25):1497614989. https://doi.org/10.1021/acsomega.0c00462 
Li Y, Wang J, Wang ZS, Pan ZJ (2020c) Variation in permeability during $\mathrm{CO} 2-\mathrm{CH} 4$ displacement in coal seams Part 2: modeling and simulation. ACS Omega 5(29):18432-18440. https://doi.org/10. 1021/acsomega.0c02293

Litvinsky GG (2007) The scientific doctrine of manless mining of thin coal seams. Tech Technol Econ Aspect Thin-seams Coal Min Int Min Forum 2007:15-24. https://doi.org/10.1201/noe0415436700. ch3

Liu T, Lin BQ, Yang W, Liu T, Zhai C (2017) An integrated technology for gas control and green mining in deep mines based on ultra-thin seam mining. Environ Earth Sci 76:243. https://doi.org/10.1007/ s12665-017-6567-z

Liu LL, Cui ZH, Wang JJ, Xia ZH, Duan LJ, Yang Y, Li M, Li T (2020) Pore size distribution characteristics of high rank coal with various grain sizes. ACS Omega 5(31):19785-19795. https://doi.org/ 10.1021/acsomega.0c02569

Lu GW, Wang JL, Wei CT, Song Y, Yan GY, Zhang JJ, Chen GH (2018a) Pore fractal model applicability and fractal characteristics of seepage and adsorption pores in middle rank tectonic deformed coals from the Huaibei coal field. J Pet Sci Eng 171:808-817. https://doi.org/10.1016/j.petrol.2018.07.074

Lu GW, Wei CT, Wang JL, Yan GY, Zhang JJ, Song Y (2018b) Methane adsorption characteristics and adsorption model applicability of tectonically deformed coals in the Huaibei coalfield. Energy Fuels 32(7):7485-7496. https://doi.org/10.1021/acs.energyfuels. $8 \mathrm{~b} 01397$

Lu GW, Wei CT, Wang JL, Zhang JJ, Quan FK, Tamehe LS (2019) Variation of surface free energy in the process of methane adsorption in the nanopores of tectonically deformed coals: a case study of middle-rank tectonically deformed coals in the Huaibei Coalfield. Energy Fuels 33(8):7155-7165. https://doi.org/10.1021/acs. energyfuels.9b01265

Lu GW, Wei CT, Wang JL, Meng RY, Tamehe LS (2020) Impacting factors, dynamic process, and correction of adsorption reduction in shale reservoir: a case study on shale samples from the western Guizhou. ACS Omega. https://doi.org/10.1021/acsomega.0c01286

Lu GW, Wei CT, Wang JL, Meng RY, Tamehe LS (2021) Influence of pore structure and surface free energy on the contents of adsorbed and free methane in tectonically deformed coal. Fuel 285:119087. https://doi.org/10.1016/j.fuel.2020.119087

Ma YL, Zhang YL (2008) Simulation experiment research on mining coal in deep inclined thin coal seam. Shanxi Coking Coal Sci Technol

Meng JQ, Li SC, Niu JX (2019) Crystallite structure characteristics and its influence on methane adsorption for different rank coals. ACS Omega 4(24):20762-20772. https://doi.org/10.1021/acsom ega.9b03165

Moore TA (2012) Coalbed methane: a review. Int J Coal Geol 101:3681. https://doi.org/10.1016/j.coal.2012.05.011

Piwniak GG, Bondarenko VI, Salli VI, Pavlenko II, Dychkovskiy RO (2007) Limits to economic viability of extraction of thin coal seams in Ukraine. Tech technol Econ Aspect Thin-seams Coal Min Int Min Forum 129-132

Quan FK, Wei CT, Feng SL, Hu YB (2020) Physical experiment and numerical simulation of the depressurization rate for coalbed methane production. ACS Omega 5(35):22661-22673. https:// doi.org/10.1021/acsomega.0c03439

Saluga P (2008) Economic conditions satisfying efficient mining of thin coal seams. Gospodarka Surowcami Mineralnymi-Min Res Manage (in Polish) 24(2):175-187

Shen J, Fu XH, Qin Y, Liu Z (2010) Control actions of structural curvature of coal-seam floor on coalbed gas in the No. 8 Coal Mine of Pingdingshan. J China Coal Soc 35(4):586-589
Song Y, Jiang B, Liu JG (2017) Nanopore structural characteristics and their impact on methane adsorption and diffusion in low to medium tectonically deformed coals: case study in the Huaibei coal field. Energy Fuels 31(7):6711-6723. https://doi.org/10.1021/ acs.energyfuels.7b00512

Tong CX, Huang HZ, He H, Wang B (2019) Chemical characteristics and development significance of trace elements in produced water with coalbed methane in Tiefa Basin. ACS Omega 4(17):1756117568. https://doi.org/10.1021/acsomega.9b02562

Vaziri V, Khademi HJ, Sayadi AR (2015) Estimation of coal gas content using geostatistical methods in GIS environment: a case study from Ta bas coal mine. Proc 24th Int Min Congress Turkey IMCET 1007-1015

Wang GM, Jiao SL, Cheng GX (2011) Fully mechanized coal mining technology for thin coal seam under complicated geological conditions. Energy Explor Exploit 29(2):169-177. https://doi.org/10. 1260/0144-5987.29.2.169

Wang F, Tu S, Bai Q (2012) Practice and prospects of fully mechanized mining technology for thin coal seams in China. J South Afr Inst Min Metall 112(2):161-170

Wang FT, Zhang C, Liang NN (2017) Gas permeability evolution mechanism and comprehensive gas drainage technology for thin coal seam mining. Energies 10(9):1382. https://doi.org/10.3390/ en10091382

Wang G, Qin Y, Xie YW, Shen J, Zhao L, Huang B, Zhao WQ (2018) Coalbed methane system potential evaluation and favourable area prediction of Gujiao blocks, Xishan coalfield, based on multi-level fuzzy mathematical analysis. J Pet Sci Eng 160:136-151. https:// doi.org/10.1016/j.petrol.2017.10.042

Wang JL, Zhai JT, Qin Y, Wang LL, Ju YW (2019) Influencing factors analysis and prediction of the loss of gas content after gas drainage in Xutuan Mine of Huaibei. China. J China Coal Soc 44(8):2401-2408

Wei JP, Hao TX, Liu MJ (2009) BP model of gas content prediction based on quantitative assessment of geological structure complexity. J China Coal Soc 34(8):1090-1094

Zhang XG, Ranjith PG, Perera MS, Ranathunga AS, Haque A (2016) Gas transportation and enhanced coalbed methane recovery processes in deep coal seams: a review. Energy Fuels 30(11):88328849. https://doi.org/10.1021/acs.energyfuels.6b01720

Zhang JJ, Wei CT, Chu XX, Vandeginste V, Ju W (2020a) Multifractal analysis in characterizing adsorption pore heterogeneity of middle- and high-rank coal reservoirs. ACS Omega 5(31):1938519401. https://doi.org/10.1021/acsomega.0c01115

Zhang ZG, Qin Y, Yi TS, You ZJ, Yang ZB (2020b) Pore structure characteristics of coal and their geological controlling factors in eastern Yunnan and western Guizhou China. ACS Omega 5(31):19565-19578. https://doi.org/10.1021/acsomega.0c02041

Zhao TB, Zhang ZY, Tan YL, Shi CZ, Wei P, Li Q (2014a) An innovative approach to thin coal seam mining of complex geological conditions by pressure regulation. Int J Rock Mech Min Sci 71:249-257

Zhao ZG, Yan JP, Liu X (2014b) Research on gas occurrence regularity in Fengcheng mining area of Jiangxi Province. Energy Explor Exploit 32(3):591-599. https://doi.org/10.1260/0144-5987.32.3. 591

Publisher's Note Springer Nature remains neutral with regard to jurisdictional claims in published maps and institutional affiliations. 